\title{
Anaerobic degradation of naphthalene and 2-methylnaphthalene by strains of marine sulfate-reducing bacteria
}

\author{
Florin Musat, ${ }^{1}$ Alexander Galushko, ${ }^{1}$ Jacob Jacob, ${ }^{1}$ \\ Friedrich Widdel, ${ }^{\text {** Michael Kube, }}{ }^{2}$ \\ Richard Reinhardt, ${ }^{2}$ Heinz Wilkes, ${ }^{3}$ Bernhard Schink ${ }^{4}$ \\ and Ralf Rabus ${ }^{1,5}$ \\ 'Max Planck Institute for Marine Microbiology, \\ Celsiusstraße 1, 28359 Bremen, Germany. \\ ${ }^{2}$ Max Planck Institute for Molecular Genetics, Ihnestraße \\ 73, 14195 Berlin, Germany. \\ ${ }^{3}$ Helmholtz Centre Potsdam GFZ German Research \\ Centre for Geosciences, Telegrafenberg, 14473 \\ Potsdam, Germany. \\ ${ }^{4}$ Microbial Ecology, Department of Biology, University of \\ Konstanz, PO Box 5560, 78457 Konstanz, Germany. \\ ${ }^{5}$ Institute for Chemistry and Biology of the Marine \\ Environment (ICBM), University of Oldenburg, \\ Carl-von-Ossietzky-Straße 9-11, 26111 Oldenburg, \\ Germany.
}

\section{Summary}

The anaerobic biodegradation of naphthalene, an aromatic hydrocarbon in tar and petroleum, has been repeatedly observed in environments but scarcely in pure cultures. To further explore the relationships and physiology of anaerobic naphthalene-degrading microorganisms, sulfate-reducing bacteria (SRB) were enriched from a Mediterranean sediment with added naphthalene. Two strains (NaphS3, NaphS6) with oval cells were isolated which showed naphthalene-dependent sulfate reduction. According to 165 rRNA gene sequences, both strains were Deltaproteobacteria and closely related to each other and to a previously described naphthalene-degrading sulfate-reducing strain (NaphS2) from a North Sea habitat. Other close relatives were SRB able to degrade alkylbenzenes, and phylotypes enriched anaerobically with benzene. If in adaptation experiments the three naphthalene-grown strains were exposed to 2-methylnaphthalene, this compound was utilized after a pronounced lag phase, indicating

Received 15 February 2008; accepted 31 July, 2008. *For correspondence. E-mail fwiddel@ mpi-bremen.de; Tel. (+49) 42120287 02; Fax (+49) 4212028790 . that naphthalene did not induce the capacity for 2-methylnaphthalene degradation. Comparative denaturing gel electrophoresis of cells grown with naphthalene or 2-methylnaphthalene revealed a striking protein band which was only present upon growth with the latter substrate. Peptide sequences from this band perfectly matched those of a protein predicted from genomic libraries of the strains. Sequence similarity (50\% identity) of the predicted protein to the large subunit of the toluene-activating enzyme (benzylsuccinate synthase) from other anaerobic bacteria indicated that the detected protein is part of an analogous 2-methylnaphthalene-activating enzyme. The absence of this protein in naphthalene-grown cells together with the adaptation experiments as well as isotopic metabolite differentiation upon growth with a mixture of $d_{8}$-naphthalene and unlabelled 2-methylnaphthalene suggest that the marine strains do not metabolize naphthalene by initial methylation via 2-methylnaphthalene, a previously suggested mechanism. The inability to utilize 1-naphthol or 2-naphthol also excludes these compounds as free intermediates. Results leave open the possibility of naphthalene carboxylation, another previously suggested activation mechanism.

\section{Introduction}

Naphthalene $\left[\mathrm{C}_{10} \mathrm{H}_{8}\right.$; melting point, $80.2^{\circ} \mathrm{C}$; solubility in $\mathrm{H}_{2} \mathrm{O}$ at $25^{\circ} \mathrm{C}, 0.24 \mathrm{mM} ; \Delta G_{f}^{\circ}=201 \mathrm{~kJ} \mathrm{~mol}^{-1}$ (Dean, 1992; Eastcott et al., 1988)], a hydrocarbon with two fused aromatic rings, is an abundant component of coal tar (first description by Brande, 1820; Garden, 1820; Kidd, 1821). Also petroleum commonly contains naphthalene (Tissot and Welte, 1984). Furthermore, naphthalene may originate from some biological sources such as endophytic fungi (Daisy et al., 2002; Ezra et al., 2004), Magnolia flowers (Azuma et al., 1996), deer hair (Gassett et al., 1997) and termite nests (Chen et al., 1998a,b) or the plants and natural soil near termite nests (Krauss et al., 2005). Naphthalene is a raw chemical for industrial syntheses, in particular of phthalic anhydride (Franck and Stadelhofer, 1987; Preuss et al., 2003). Human exposure to naphthalene was formerly not uncommon due to its 
(now obsolete) use as a moth repellent. Naphthalene at high concentration may cause haemolytic anaemia and some other conditions, whereas the tumorigenic potential is presently considered low (Umweltbundesamt, 2007; Bogen et al., 2008).

Being a potential environmental contaminant from tar or petroleum and representing the 'archetype' of polycyclic aromatic hydrocarbons, naphthalene has early become of interest as a study substrate in biodegradation research (overview by Gibson and Subramanian, 1984). Accordingly, aerobic naphthalene degradation has been known since several decades and has been studied in much detail on the molecular level (Habe and Omori, 2003; Karisson et al., 2003).

In contrast, the capacity for anaerobic biodegradation of naphthalene has become evident relatively recently, in most cases from observations in anoxic habitats and microcosms under conditions of nitrate reduction, sulfate reduction or methanogenesis (Thierrin et al., 1993; Coates et al., 1996; 1997; Langenhoff et al., 1996; Bedessem et al., 1997; Sharak Genthner et al., 1997; Zhang and Young, 1997; Hayes et al., 1999; Hayes and Lovley, 2002; Rothermich et al., 2002). Reports on the isolation and physiology of anaerobic naphthalene degraders are scarce. Pseudomonas- and Vibrio-like strains isolated under oxic conditions from tar-contaminated marine sediment were reported to mineralize naphthalene partially under conditions of denitrification (Rockne and Strand, 1998, 2001; Rockne etal., 2000). A marine sulfatereducing bacterium (SRB), strain NaphS2, was isolated that grew with naphthalene under strictly anoxic conditions (Galushko et al., 1999). In addition, a highly enriched sulfate-reducing freshwater culture has been studied which utilized naphthalene anaerobically (Meckenstock et al., 2000; Annweiler et al., 2002; Safinowski and Meckenstock, 2006).

The initial biochemical steps in anaerobic naphthalene degradation are insufficiently understood. Naphthalene is rather unreactive, due to the stabilizing aromatic $10 \pi$ electron system and lack of alkyl or polar groups. Still, it reacts more readily than benzene, for instance, with electrophilic and hydrogenating agents. According to present knowledge, naphthalene hydroxylation by use of a reactive oxygen species as in aerobic bacteria (Karlsson et al., 2003) is excluded or not expected in an anaerobic metabolism with sulfate or nitrate as electron acceptors. After the suggestion of anaerobic hydroxylation through dehydrogenation to a naphthol (Bedessem et al., 1997) or carboxylation to 2-naphthoate (Zhang and Young, 1997; Annweiler et al., 2002), methylation of naphthalene has become an attractive hypothesis (Safinowski and Meckenstock, 2006; Safinowski et al., 2006). The formed 2-methylnaphthalene would subsequently react with fumarate to yield (2-naphthylmethyl)succinate (Annweiler et al., 2000), analogous to the anaerobic reaction of toluene yielding benzylsuccinate (Heider, 2007).

Considering the scarcity of pure cultures that degrade naphthalene anaerobically, the present study was undertaken to enrich and isolate further strains with such capacity so as to gain insights into their phylogenetic relationships and degradative capacities; this task also included an examination of the discussed possibilities for naphthalene activation. Since capacities for anaerobic biodegradation of various hydrocarbons are apparently widespread among marine SRB (Widdel et al., 2007), the present study employed marine sediment as starting material and sulfate as electron acceptor.

\section{Results and discussion}

\section{Enrichment, isolation and characterization}

Anaerobically incubated medium containing sediment from a Mediterranean lagoon, sulfate and naphthalene (in an inert liquid carrier phase as a non-toxic reservoir) exhibited significant sulfide formation in comparison with a naphthalene-free control (up to 18 versus $9 \mathrm{mM}$ sulfide) within 8 months. Subcultures (10\% inoculum, v/v) reached $18 \mathrm{mM}$ sulfide within 6-7 weeks. Microscopy of sediment-free subcultures revealed oval to rod-shaped cells, several of which contained light-refracting vesicles. Anoxic agar dilution series essentially yielded two distinct types of colonies. The beige colonies were either slightly translucent and consisted of vesicle-free cells, or they were opaque ('chalky') and consisted of cells with vesicles. One strain of each cell type was isolated (Fig. 1). The isolates are referred to as strains NaphS3 (without vesicles) and NaphS6 (with vesicles).

In purity tests with strain NaphS3, cell types other than in the inoculum were not detectable. However, the purity tests with strain NaphS6 employing pyruvate, lactate or fumarate revealed the presence of an accompanying spirilloid SRB with much smaller and curved cells. In cultures grown with naphthalene or other aromatic substrates (see below), these cells occurred at low numbers (approximately $3 \%$ of total); considering their size, their estimated biovolume contribution $(<0.3 \%$ ) during growth of strain NaphS6 with aromatic growth substrates is therefore negligible.

Sequence comparison of 16S rRNA genes of strains NaphS3, NaphS6 and the formerly isolated naphthalene degrader, strain NaphS2 from North Sea sediment (Galushko et al., 1999), revealed an affiliation with the Desulfobacteraceae (Deltaproteobacteria) and significant sequence similarity among each other (NaphS3-NaphS6, 97.5\%; NaphS3-NaphS2, 99.8\%; NaphS6-NaphS2, 97.4\%; Fig. 2). Other close relatives were marine SRB previously isolated with $m$-xylene (Harms et al., 1999) 

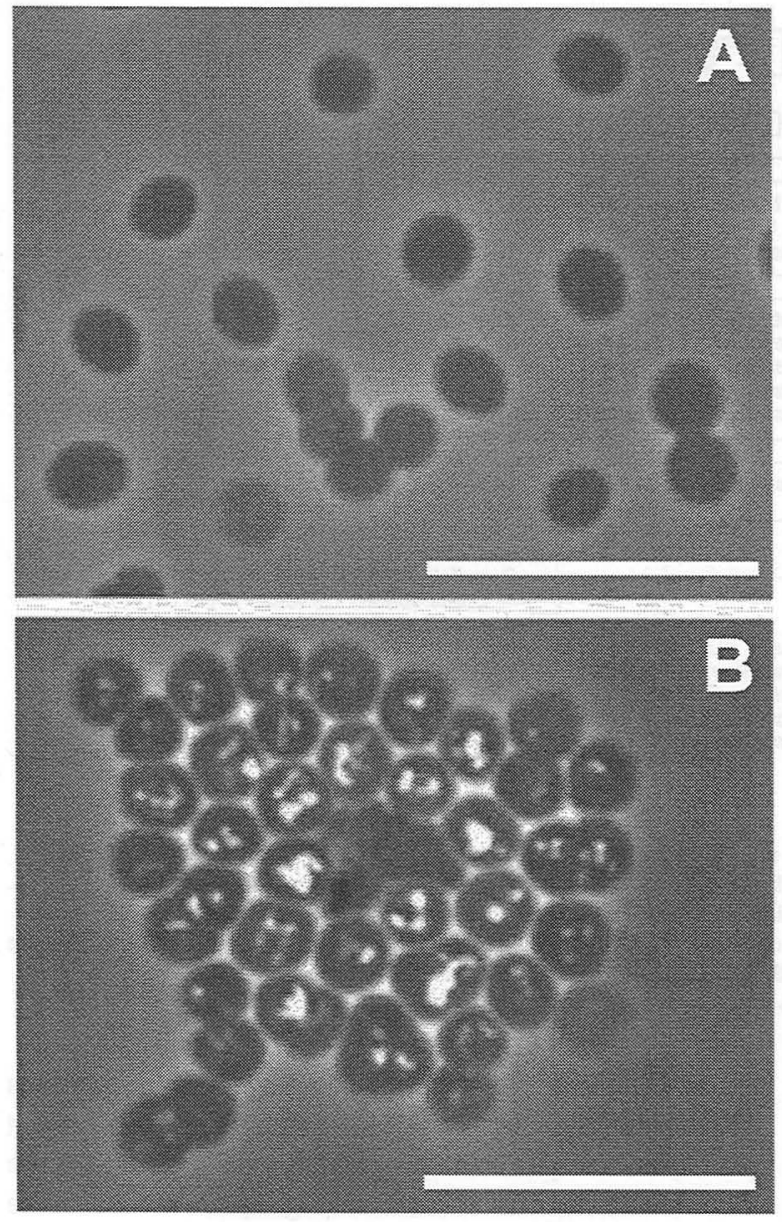

Fig. 1. Phase-contrast images of viable cells of sulfate-reducing bacteria isolated and grown anaerobically with naphthalene. Bars, $10 \mu \mathrm{m}$.

A. Strain NaphS3.

B. Strain NaphS6, with characteristic gas vesicles. This strain tended to aggregate loosely around small flocs of FeS (from trace element solution).

and ethylbenzene (Kniemeyer et al., 2003), as well as sequence clones retrieved from enrichment cultures with benzene (Phelps et al., 1998; Musat and Widdel, 2008).

If cells of strain NaphS6 were exposed to pressure by centrifugation or inside a $1 \mathrm{ml}$ syringe with application of a jerky push, the light-refracting vesicles disappeared (collapsed), which is characteristic of gas vesicles (Walsby, 1994). Gas vesicles have been observed in a few SRB (Widdel, 1988) including the closely related ethylbenzene-degrading strain EbS7 (Kniemeyer et al., 2003). The role of gas vesicles in SRB is unknown.

In addition to naphthalene, strains NaphS2, NaphS3 and NaphS6 also utilized 2-methylnaphthalene (1\% in carrier phase) and 2-naphthoate (1 mM), but not 1-methylnaphthalene or 1-naphthoate at the same concentrations. Benzoate $(2 \mathrm{mM})$ was utilized by strains
NaphS2 and NaphS3, but not so far by strain NaphS6. In substrate tests with 1-naphthol and 2-naphthol, possible toxic effects of these compounds (as two-ring analogues of phenol) had to be excluded. If they were added at concentrations of $0.2 \mathrm{mM}$ to naphthalene cultures, sulfide production was completely inhibited. Only concentrations of $\leq 0.1 \mathrm{mM}$ were non-toxic. However, even at low, non-toxic concentrations, consumption of naphthols was insignificant (experiment with 1-naphthol depicted in Fig. S1).

Naphthalene consumption and sulfide formation were quantified in growth experiments. Per mol naphthalene consumed in the cultures of strains NaphS3 and NaphS6, the measured sulfide formation was 6.6 and $4.9 \mathrm{~mol}$ respectively. This indicates the capacity for complete oxidation, according to $\mathrm{C}_{10} \mathrm{H}_{8}+6 \mathrm{SO}_{4}{ }^{2-}+2 \mathrm{H}^{+}+6 \mathrm{H}_{2} \mathrm{O} \rightarrow$ $10 \mathrm{HCO}_{3}{ }^{-}+6 \mathrm{H}_{2} \mathrm{~S}$. The apparent surplus of sulfide in one experiment is explained by a transfer of carrier phase droplets from the naphthalene-containing carrier phase in the pre-culture. The capacity for complete naphthalene oxidation was previously demonstrated with strain NaphS2 (Galushko et al., 1999).

Test of 2-methylnaphthalene as a possible intermediate of naphthalene degradation

The observed failure of strains NaphS2, NaphS3 and NaphS6 (pre-grown with naphthalene) in the substrate tests to utilize naphthols (see above and Fig. S1) excludes them as free intermediates during naphthalene degradation, assuming that their hydrophobicity allows diffusion into the cells (see analogous discussion for phenol; Musat and Widdel, 2008).

In contrast, the utilization of 2-methylnaphthalene in the growth tests leaves open the possibility that this compound is an intermediate during naphthalene degradation. Via the suggested methylation (Safinowski and Meckenstock, 2006), naphthalene would be channelled into the pathway of 2-methylnaphthalene by a single and 'elegant' step. Naphthalene is indeed susceptible to electrophilic substitution so that $S$-adenosylmethionine or methyl-coenzyme $B_{12}$ could, in principle, serve as co-substrates $\left(\mathrm{CH}_{3}{ }^{+}\right.$donors). 2-Methylnaphthalene as a hydrophobic compound is expected to diffuse freely into the cells, like naphthalene. If naphthalene degradation in the marine SRB occurs via 2-methylnaphthalene, naphthalene-grown cells should utilize 2-methylnaphthalene without an induction phase. Whereas such a response is a requisite albeit not a sufficient proof of the role of 2-methylnaphthalene as an intermediate (there might be an independent constitutive utilization), the lack of a response would rule out this compound as an intermediate as long as the added concentration is not toxic. The non-toxic concentration $(\leq 1 \%$ in the carrier 


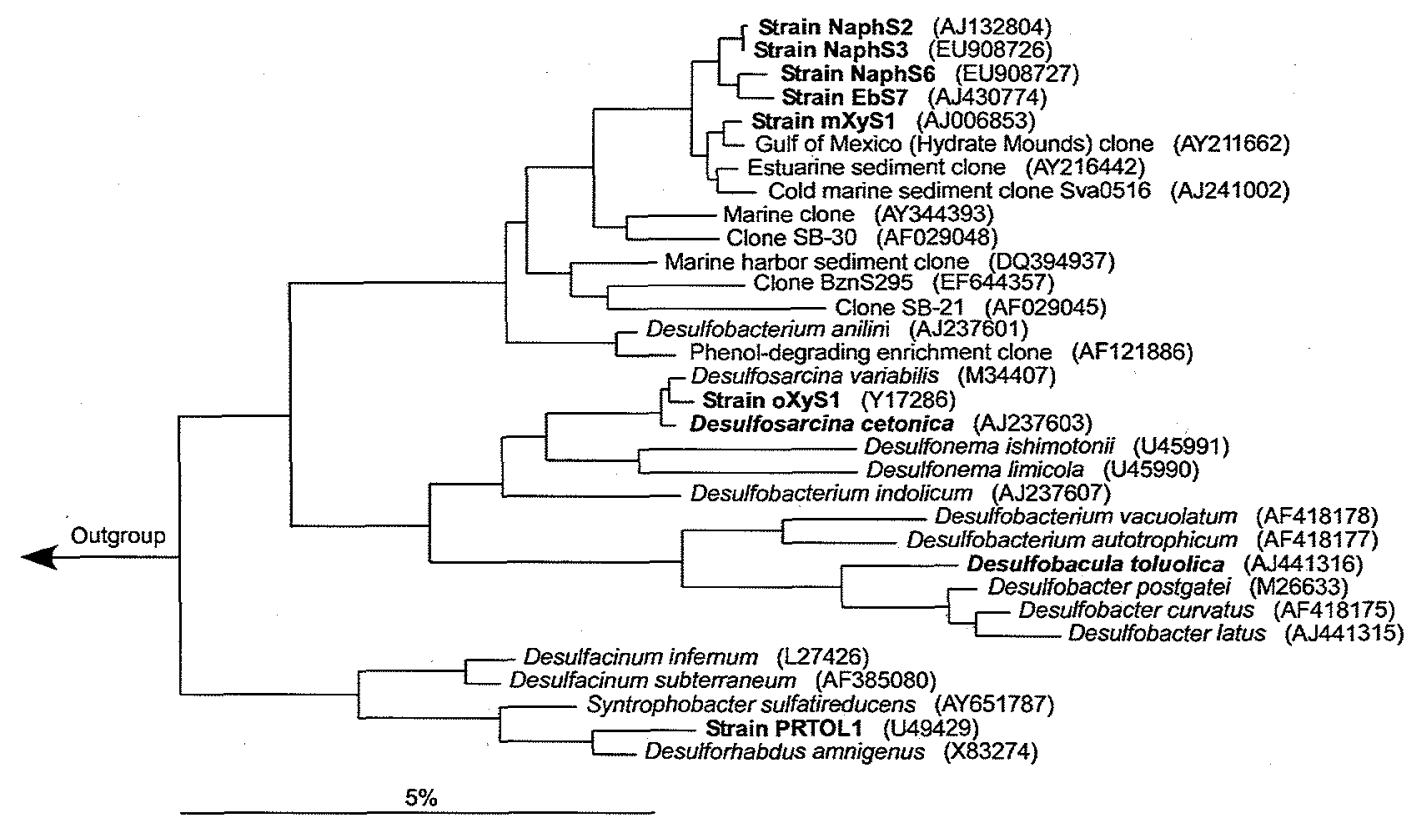

Fig. 2. Phylogenetic $16 S$ rRNA-based affiliation of the presently isolated sulfate-reducing strains NaphS 3 and NaphS6 (from Mediterranean lagoon) and the previously isolated strain NaphS2 (from a North Sea harbour; Galushko et al., 1999). Sulfate-reducing isolates able to degrade aromatic hydrocarbons are indicated in bold, their substrates being as follows: EbS7, ethylbenzene (Kniemeyer et al., 2003); mXyS1, toluene and m-xylene (Harms et al., 1999); oXyS1, toluene and o-xylene (Harms et al., 1999); Desulfosarcina cetonica, Desulfobacula toluolica and PRTOL1, toluene. Clones SB-21, SB-30 (Pheips et al., 1998) and BznS295 (Musat and Widdel, 2008) were retrieved from sulfate-reducing enrichments with benzene. The scale bar represents $5 \%$ estimated sequence divergence.

phase) was verified during the substrate tests (see above). The tests always included parallel controls with naphthalene alone to verify that all used cell batches were in an active state. If naphthalene-grown cells were exposed to 2-methylnaphthalene, sulfide formation began only after a pronounced lag phase (Fig. 3). According to this result, 2-methylnaphthalene is unlikely to be an intermediate during naphthalene degradation by the three marine strains. If in an additional control the three strains were grown with 2-methylnaphthalene, they immediately began to consume this compound again upon its addition.

The present results are analogous to those obtained with a benzene-grown sulfate-reducing marine enrichment culture which was unlikely to involve free phenol or toluene as an intermediate (Musat and Widdel, 2008).

\section{Electrophoretic display of major proteins formed with different substrates}

If extracts from cells of the three strains grown with naphthalene or 2-methylnaphthalene were subjected to denaturing gel electrophoresis, the most obvious difference between the protein patterns were 2-methylnaphthalenespecific co-migrating bands of high molecular mass (Fig. 4). Their peptide sequences perfectly matched those of gene products predicted from genomic shotgun librar- ies of the three strains (Fig. S2). These gene products showed sequence similarity to the catalytic (large) subunit (BssA) of benzylsuccinate synthase, the enzyme for the anaerobic activation of toluene (Fig. 5). Based on these similarities, we assume that the 2-methylnaphthalenespecific band in strains NaphS2, NaphS3 and NaphS6 represents the catalytic subunit of the 2-methylnaphthalene-activating enzyme (2-naphthylmethyl) succinate synthase, which may be termed Nms. This enzyme has not been purified and characterized thus far, but high similarity to benzylsuccinate synthase is expected, due to the activation of a methyl group next to an aromatic ring, and addition to fumarate. The predicted NmsA protein also reveals the possible radical-bearing glycine (Fig. S2; Heider, 2007). The apparent absence of the striking protein band in naphthalene-grown cells again indicates that naphthalene degradation in the marine strains is unlikely to occur via 2-methylnaphthalene.

Other proteins related to the apparent (2-naphthylmethyl)succinate synthase subunit were predicted enzymes for the anaerobic activation of alkanes (Callaghan et al., 2008; Grundmann et al., 2008; Fig. 5). Hence, the presently known or assumed fumaratedependent hydrocarbon-activating enzymes constitute three phylogenetic sub-branches, in accordance with their different substrates (toluene, 2-methylnaphthalene, n-alkanes). 

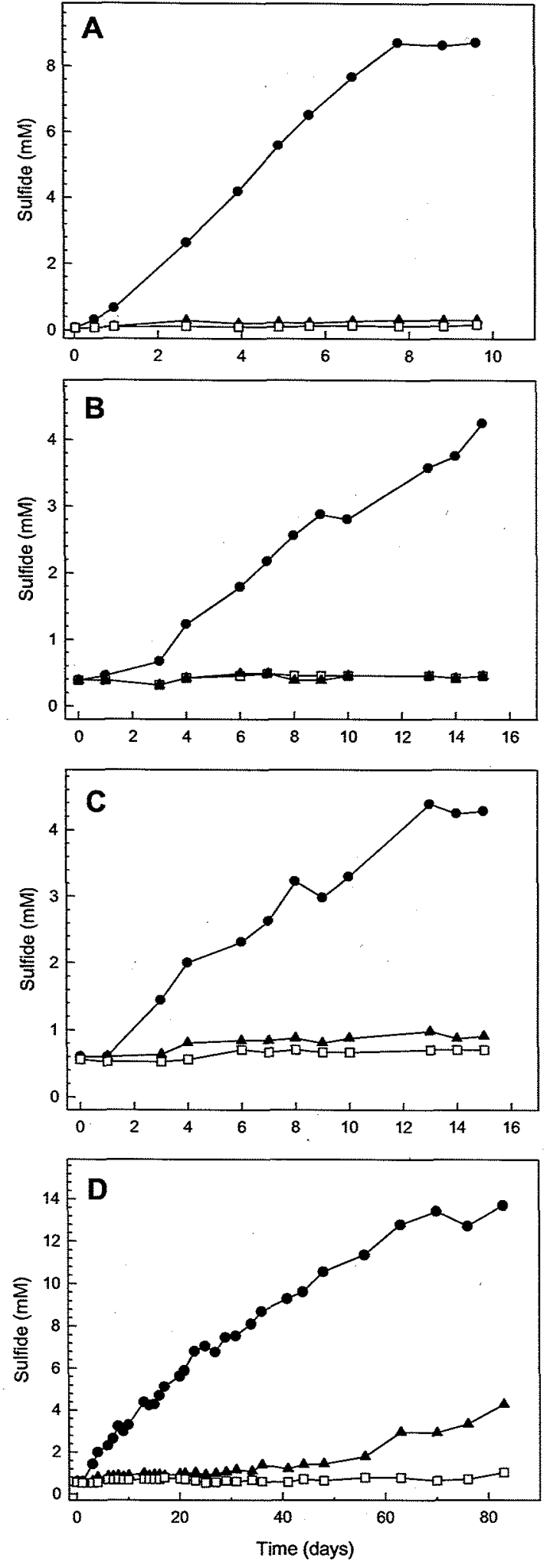

Fig. 3. Incubation of naphthalene-grown cells of strains NaphS2 (A), NaphS3 (B) and NaphS6 (C and D) with 2-methyinaphthalene and naphthalene. Comparison of sulfide formation with

2 -methylnaphthalene (A), with naphthalene (O, positive control) and without any addition ( $\square$, negative control) shows that there was no initial activity towards 2-methylnaphthalene. The capacity was induced after more than 20 days, as depicted for strain NaphS6 (D).

\section{Chemical analysis of metabolites}

In accordance with other findings (Zhang and Young, 1997; Annweiler et al., 2000; 2002; Galushko et al., 2003; Safinowski and Meckenstock, 2006), the polar compound 2-naphthoate was detected (as methyl ester upon derivatization) in both, naphthalene- and 2-methylnaphthalene-grown cultures. 2-Naphthoate or naphthoyl-CoA is an expected central intermediate in the degradation of naphthalene and 2-methylnaphthalene (Fig. S4), as benzoyl-CoA is a central intermediate in the anaerobic degradation of many monoaromatic compounds (Boll et al., 2002). Agreeing with an earlier report (Zhang and Young, 1997), cells grown with naphthalene in the presence of ${ }^{13} \mathrm{C}$-bicarbonate incorporated the label into the carboxyl function of 2-naphthoate, according to mass spectrometric fragmentation. Even though this result cannot exclude naphthalene methylation (a methyl group may be derived from $\mathrm{CO}_{2}$ ), such a reaction is unlikely in view of the other results obtained with the marine strains.

The most obvious metabolite in 2-methylnaphthalenegrown cultures was (2-naphthylmethyl)succinate, the amount being 20 -fold higher than that of 2-naphthoate. Surprisingly (2-naphthylmethyl)succinate was also detected in some (but not all) naphthalene-grown cultures of the three strains; however, the amount of (2-naphthylmethyl)succinate was c.100-fold lower than that of 2-naphthoate. 2-Methyinaphthalene was detected neither (as a possible impurity) in the added naphthalene nor (as a possible metabolite) in the naphthalene-grown cultures. Because the other experiments with the marine strains did not support naphthalene methylation and subsequent conversion to (2-naphthylmethyl)succinate, one present explanation for the detection of traces of this compound in some naphthalene cultures is its formation from the postulated intermediate, 2-naphthoyl-CoA via side-reactions. With exception of the special, possibly highly synthesis-controlled (2-naphthylmethyl)succinate synthase, the more 'usual' enzymes for the assumed subsequent $\beta$-oxidation-like conversion of (2-naphthylmethyl)succinate to 2-naphthoyl-CoA and succinyl-CoA (Annweiler et al., 2000) may be present at a certain level (or constitutive) during growth with naphthalene. Since this conversion is reversible from a biochemical point of view, a reverse (reductive) reaction sequence 


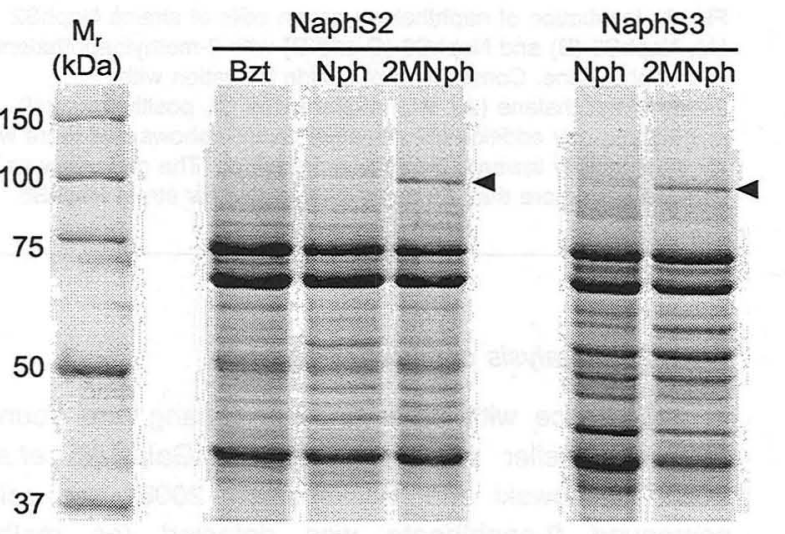

starting with naphthoyl-CoA (formed from naphthalene via still unexplored reactions) and succinyl-CoA (a ubiquitous metabolite) could lead to minor amounts of (2-naphthylmethyl)succinate during growth with naphthalene (Fig. S4).

To further substantiate that naphthalene in the marine strains is not metabolized via 2-methylnaphthalene, a naphthalene-grown culture of strain NaphS2 was cultivated with a mixture of deuterated naphthalene $\left(d_{8}-\right.$ naphthalene) and unlabelled 2-methylnaphthalene. Mass spectrometric analysis of metabolite labelling revealed that the major proportion ( $86 \%$ ) of the common intermediate, 2-naphthoate, was deuterated and hence derived from naphthalene. Naphthalene in this experiment was obviously metabolized to a greater extent than 2-methylnaphthalene. Nevertheless, almost all (>99.5\%) of the detected (2-naphthylmethyl)succinate was unlabelled and thus derived from 2-methylnaphthalene. This

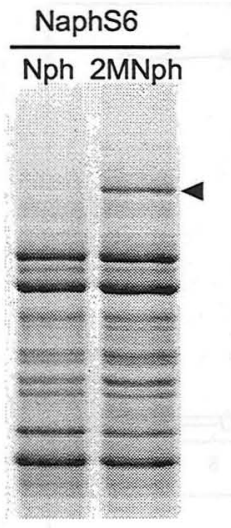

Fig. 4. Denaturing gel electrophoresis (SDS-PAGE) of cell extracts from strains NaphS2, NaphS3 and NaphS6 grown with benzoate (Bzt), naphthalene (Nph) or 2-methylnaphthalene (2MNph). Mass spectrometry of peptides from the

2-methylnaphthalene-specific band (arrowhead) allowed identification of a genome-deduced protein from each strain (see Fig. S2) with sequence similarity (see Fig. 5) to the catalytic subunit of benzylsuccinate synthase (BssA), which activates toluene anaerobically.

result cannot be explained by naphthalene metabolism via 2-methylnaphthalene (Fig. S5).

As observed elsewhere (Sullivan et al., 2001), 2-methylnaphthalene-grown cultures also formed isomers of methylnaphthoate, $\mathrm{H}_{3} \mathrm{C}-\left(\mathrm{C}_{10} \mathrm{H}_{6}\right)-\mathrm{COO}^{-}$(Fig. S6). These metabolites were not detected in naphthalene-grown cultures. 2-Methylnaphthalene apparently not only underwent fumarate addition yielding (2-naphthylmethyl)succinate (presumably the main reaction) but also an alternative addition of a carboxyl group as occurring with naphthalene. If cultures were grown with naphthalene in the presence of 1-methylnaphthalene, which is not a growth substrate, other isomers of methylnaphthoates were detected. These were probably dead-end metabolites from a co-activation of 1-methylnaphthalene by the naphthalene-activating enzyme, similar as reported previously (Safinowski et al., 2006). There was no evidence that the carboxyl function of the methylnaphthoates origi-

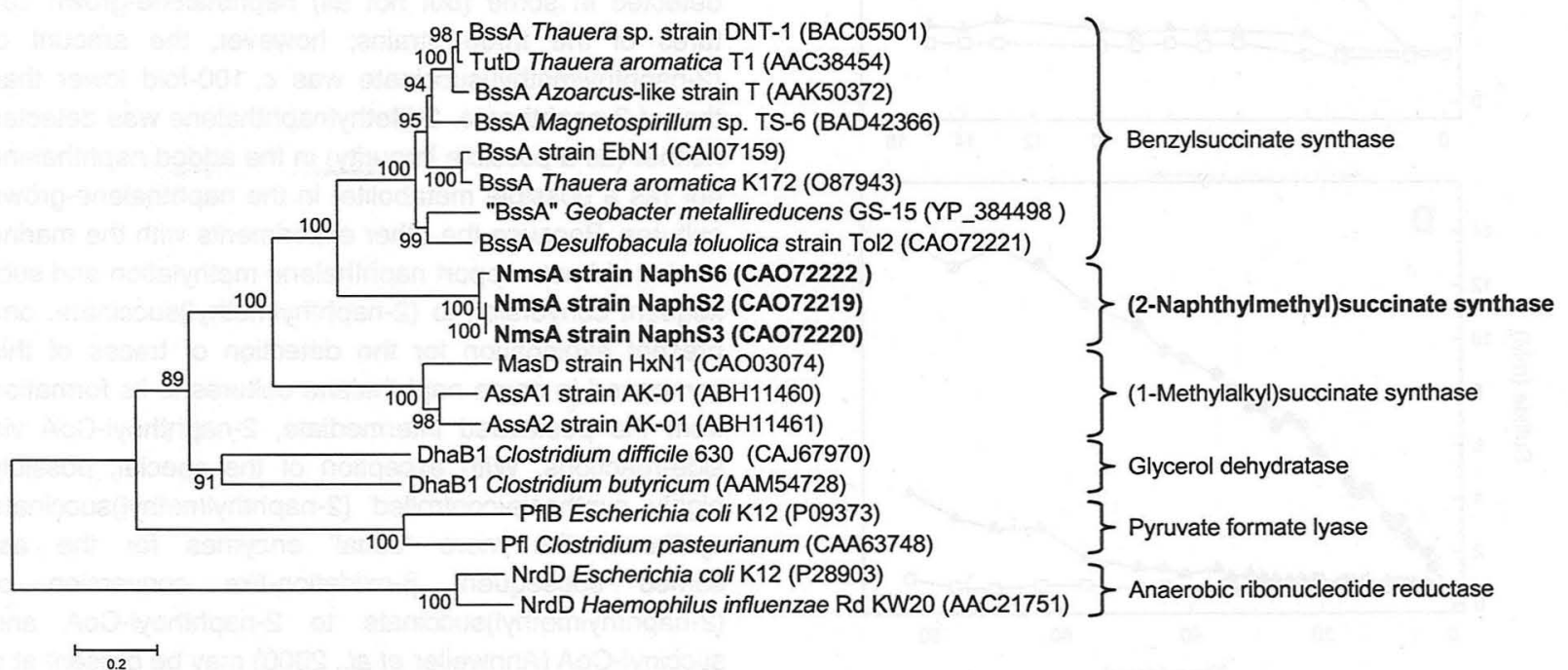

Fig. 5. Sequence similarity of the proteins specifically formed with 2-methylnaphthalene (Fig. 4), the assumed large subunit of (2-naphthylmethyl)succinate synthase, NmsA, with other glycyl radical proteins. For sequence alignment of the 2-methylnaphthalene-specific proteins see Fig. S3. 
nated from a preceding methylation and subsequent metabolism via fumarate addition, because [(methyl-2naphthyl)methyl]succinates were not detectable.

\section{Concluding remarks}

In view of the substrate adaptation experiments, the 2-methylnaphthalene-specific proteins and the isotopic differentiation of metabolites, an activation of naphthalene through methylation is unlikely in the presently studied marine SRB. However, we cannot exclude that this reaction is used, as suggested, for naphthalene activation in a different, terrestrial sulfate-reducing culture (Safinowski and Meckenstock, 2006). The present experiments leave open the possibility for naphthalene activation by carboxylation (Zhang and Young, 1997; Annweiler et al., 2002), a mechanism also suggested for the other unsubstituted aromatic hydrocarbons, benzene (Caldwell and Suflita, 2000) and phenanthrene (Zhang and Young, 1997; Davidova et al., 2007). An activation by hydrogen atom abstraction and addition to fumarate is presently regarded as unlikely. The resulting product, naphthylsuccinate, has never been observed. Also, such hydrogen abstraction would have to overcome a very high $\mathrm{C}-\mathrm{H}$ bond strength (469 $\mathrm{kJ} \mathrm{mol}^{-1}$; Reed and Kass, 2000) in comparison with that of the methyl group of toluene or at the secondary carbon atom of alkanes (368 and $398 \mathrm{~kJ} \mathrm{~mol}^{-1}$ respectively; McMillen and Golden, 1982).

\section{Experimental procedures}

\section{Source of bacteria and cultivation}

Black (anoxic) sediment for enrichment cultures was collected from a Mediterranean lagoon, Étang de Berre (France), and stored under nitrogen at $12^{\circ} \mathrm{C}$. Strain NaphS2 has been maintained since its isolation (Galushko et al., 1999 ) in the laboratory.

Techniques used for preparation of media and anaerobic cultivation were as described elsewhere (Widdel and Bak, 1992; Galushko et al., 1999; Widdel et al., 2004). Enrichments and subcultures were grown in flat $200 \mathrm{ml}$ bottles; they were provided with $110 \mathrm{ml}$ of $\mathrm{HCO}_{3}{ }^{-} / \mathrm{CO}_{2}$-buffered sulfide-reduced artificial seawater medium, $10 \mathrm{ml}$ of inoculum, $5-7 \mathrm{ml}$ of $2,2,4,4,6,8,8$-heptamethylnonane as an inert, insoluble carrier phase containing naphthalene (20 mg ml${ }^{-1}$ ), a head space of an $\mathrm{N}_{2}-\mathrm{CO}_{2}$ mixture $(9: 1, \mathrm{v} / \mathrm{v})$, and black stoppers (Wheaton). Culture bottles were incubated nearly horizontally with the stoppers below the medium surface so as to avoid their contact with the hydrocarbon phase (Widdel et al., 2004). Cultures containing sediment were only briefly $(5 \mathrm{~s})$ shaken every 2 days while consecutive sediment-free cultures were incubated with slow horizontal shaking (50 r.p.m.) or magnetic stirring (100 r.p.m.). All cultures were incubated at $28^{\circ} \mathrm{C}$.

Bacterial strains were isolated under anoxic conditions via serial agar dilutions (Widdel and Bak, 1992). The agar in the tubes was overlaid with naphthalene in heptamethylnonane (Galushko et al., 1999). For purity tests, inocula were transferred to media containing yeast extract $\left(0.5 \mathrm{~g} \mathrm{l}^{-1}\right)$ and pyruvate, lactate, fumarate or glucose (always $1 \mathrm{mM}$ ). Cells from purity and substrate tests were regularly examined microscopically.

In substrate tests, methylnaphthalenes were provided like naphthalene in heptamethylnonane, the concentration being $10 \mathrm{mg} \mathrm{ml}^{-1}$. Naphthoates and benzoate were added from aqueous $0.2 \mathrm{M}$ stock solutions prepared from the acids and $\mathrm{NaOH}$. Naphthols were added from $2 \mathrm{mM}$ stock solutions in seawater medium; the poorly soluble, solid compounds were dissolved by shaking for 1 day.

\section{Adaptation experiments}

To prepare metabolically active concentrated cell suspensions, a total volume of 11 combined from naphthalenegrown cultures was separated inside an anoxic chamber from the liquid carrier phase by means of a separatory funnel and centrifuged under an $\mathrm{N}_{2}-\mathrm{CO}_{2}$ mixture $(9: 1, \mathrm{v} / \mathrm{v})$. Cells were re-suspended in $300 \mathrm{ml}$ of anoxic medium. Aliquots of $100 \mathrm{ml}$ for individual experiments were distributed into anoxic $130 \mathrm{ml}$ bottles and provided with $3.7 \mathrm{ml}$ of heptamethylnonane containing naphthalene $\left(20 \mathrm{mg} \mathrm{ml}^{-1}\right)$ or 2-methylnaphthalene $\left(10 \mathrm{mg} \mathrm{ml}^{-1}\right)$. Consumption of naphthols or formation of sulfide (in case of naphthalene or 2-methylnaphthalene) was followed by chemical analysis of samples that were withdrawn with $\mathrm{N}_{2}$-flushed syringes.

\section{Chemical analyses}

Sulfide was quantified photometrically as fresh colloidal CuS (Cord-Ruwisch, 1985).

Naphthalene in the carrier phase was measured with an AutoSystem gas chromatograph (Perkin Elmer) equipped with a fused silica capillary column (OPTIMA 5, MachereyNagel; length, $50 \mathrm{~m}$; inner diameter, $0.32 \mathrm{~mm}$; film thickness, $0.25 \mu \mathrm{m}$ ) and a flame ionization detector. $\mathrm{H}_{2}$ was used as carrier gas. The oven temperature was programmed from $40^{\circ} \mathrm{C} \mathrm{(5} \mathrm{min} \mathrm{isothermal)} \mathrm{to} 200^{\circ} \mathrm{C}$ at a rate of $5^{\circ} \mathrm{C} \mathrm{min}-1$ and further to $320^{\circ} \mathrm{C} \mathrm{(5} \mathrm{min} \mathrm{isothermal)} \mathrm{at} \mathrm{a} \mathrm{rate} \mathrm{of} 20^{\circ} \mathrm{C} \mathrm{min}-1$.

Naphthols were measured by using a high-performance liquid chromatograph (Sykam) with an IBJ A3 column $(4 \times 60 \mathrm{~mm})$. Elution was by $20 \mathrm{mM} \mathrm{NaCl}$ in $45 \%(\mathrm{v} / \mathrm{v})$ aqueous ethanol at a flow rate of $1 \mathrm{mI} \mathrm{min}^{-1}$ at $50^{\circ} \mathrm{C}$. Naphthols were detected at $220 \mathrm{~nm}$ with an S 3200 UV detector (Sykam).

To analyse metabolites of naphthalene and 2-methylnaphthalene degradation, cultures grown with these substrates were acidified and extracted essentially as described (Rabus et al., 2001) using dichloromethane as solvent. Methylated extracts were analysed by gas chromatography-mass spectrometry either with a type 6890 gas chromatograph (Hewlett Packard) connected to a type 95XL mass spectrometer, or with a Trace GCMS (Thermoelectron, Dreieich, Germany) as described (Wilkes et al., 2000; Rabus et al., 2001; Wöhlbrand et al., 2008). Separation of methyl-2-naphthoic acid methyl esters was achieved on a fused silica capillary column (SGE BP21; 
length, $25 \mathrm{~m}$; inner diameter, $0.22 \mathrm{~mm}$; film thickness, $0.25 \mu \mathrm{m})$. The oven temperature was programmed from $50^{\circ} \mathrm{C}$ (1 min isothermal) to $240^{\circ} \mathrm{C}(30 \mathrm{~min}$ isothermal) at a rate of $3^{\circ} \mathrm{C} \mathrm{min}^{-1}$.

\section{S rRNA-based analyses}

Extracted DNA (Zhou et al., 1996) was used for almost fulllength 165 rRNA gene amplification by polymerase chain reaction (PCR) using the Bacteria-specific primers $8 f$ (Hicks et al., 1992) and 1492r (Kane et al., 1993). Products were purified with the QIAquick Purification Kit (Qiagen) and cloned into the pCR4 vector (Invitrogen) that were used to transform Escherichia coli Top10 (Invitrogen). Positive clones were sequenced using the $A B \mid$ Prism BigDye Terminator $v 3.0$ cycle sequencing kit and an ABI Prism 3100 Genetic Analyser (Applied Biosystems). The procedure for strain NaphS3 included 25 PCR cycles. In case of strain NaphS6, amplification of the sequence from the contaminant which occurred at low number was avoided by using only 20 PCR cycles. Subsequent direct sequencing, which did not show a contaminating sequence, and sequencing after cloning always yielded identical sequences, indicating their origin from the abundant cell type.

Sequences were assembled using the DNA Baser software (http://www.dnabaser.com). The sequences were aligned with those from the SILVA database (http://www.arb-silva.de). Phylogenetic trees were constructed by tools of the ARB software package (Ludwig et al., 2004) using maximum likelihood analysis and applying different sets of filters. Only almost full-length sequences $(>1400 \mathrm{bp}$ ) were used for tree construction.

\section{Protein analysis and shotgun sequencing of genomic DNA}

Preparation of cell lysates of naphthalene- or 2-methylnaphthalene-grown cells, sodium dodecylsulfate gel electrophoresis and Coomassie blue staining were performed as described (Rabus and Heider, 1998). The 2-methylnaphthalene-specific bands were excised for analysis by mass spectrometry (MS). Peptide masses (via MS) and sequences (via MS/MS) were determined as described (Hufnagel and Rabus, 2007). Peptide masses and peptide fragment fingerprints were mapped to the in silico digests of the predicted proteins by using the MS-Digest program (Clauser et al., 1999).

Isolation of genomic DNA and generation of plasmid libraries (average insert size of 1.8 and $3.5 \mathrm{~kb}$ ) were carried out as described (Rabus et al., 2002). Whole-genome shotgun sequencing was performed via dye terminator sequencing using $A B I 3730 X L$ capillary sequencers. Shotgun sequences were assembled using PHRAP (http://www.phrap.org). The assembly was edited and verified using Consed (Gordon, 2004) for selected sequences of the draft.

Potentially coding sequences were predicted by Glimmer 3 and manually curated in Artemis, as described (Rabus et al., 2002). Gene sequences encoding the assumed large subunit of (2-naphthylmethyl)succinate synthase ( $\mathrm{NmsA}$ ) were identified by searching with peptide masses and sequences.
Sequence quality of the identified $n m s A$ genes was manually inspected.

The MEGA 3.1 program was used for alignment and tree construction (Kumar et al., 2004) of glycyl radical enzymes. Full-length amino acid sequences were aligned with CLUSTALW using the Gonnet matrix. A consensus neighbourjoining tree was constructed. Inferred phylogeny was tested by bootstrap analysis (1000 replications).

\section{Data deposition}

The 16S rRNA gene sequences of the presently obtained isolates, strains NaphS3 and NaphS6, have been submitted to GenBank under Accession Nos EU908726 and EU908727 respectively. The previously determined $16 \mathrm{~S}$ rRNA sequence from strain NaphS2 is available under GenBank Accession No. AJ132804. Nucleotide sequences of the $n m s A$ genes that encode the assumed 2-methylnaphthalene-activating enzyme, (2-naphthylmethyl)succinate synthase, in strains NaphS2, NaphS3 and NaphS6, have been submitted to EMBL/GenBank/DDBJ under Accession Nos CU466266, CU466267 and CU466269, respectively.

\section{Acknowledgements}

We thank Ramona Appel (Bremen) and Ines Müller (Berlin) for technical assistance. This work was supported by the Max-Planck-Gesellschaft, the Deutsche Forschungsgemeinschaft (grant to B.S.) and the European Community project MATBIOPOL (EVK3-CT1999-00010; grant to F.W.).

\section{References}

Annweiler, E., Materna, A., Safinowski, M., Kappler, A., Richnow, H.H., Michaelis, W., and Meckenstock, R.U. (2000) Anaerobic degradation of 2-methylnaphthalene by a sulfate-reducing enrichment culture. Appl Environ Microbiol 66: 5329-5333.

Annweiler, E., Michaelis, W., and Meckenstock, R.U. (2002) Identical ring cleavage products during anaerobic degradation of naphthalene, 2-methylnaphthalene, and tetralin indicate a new metabolic pathway. Appl Environ Microbiol 68: 852-858.

Azuma, H., Toyota, M., Asakawa, Y., and Kawano, S. (1996) Naphthalene - a constituent of Magnolia flowers. Phytochemistry 42: 999-1004.

Bedessem, M.E., Swoboda-Colberg, N.G., and Colberg, P.J.S. (1997) Naphthalene mineralization coupled to sulfate reduction in aquifer-derived enrichments. FEMS Microbiol Lett 152: 213-218.

Bogen, K.T., Beson, J.M., Yost, G.S., Morris, J.B., Dahl, A.R., Clewell, H.J., et al. (2008) Naphthalene metabolism in relation to target tissue anatomy, physiology, cytotoxicity and tumorigenic mechanism of action. Regul Toxicol Pharmacol 51: 27-36.

Boll, M., Fuchs, G., and Heider, J. (2002) Anaerobic oxidation of aromatic compounds and hydrocarbons. Curr Opin Chem Biol 6: 604-611.

Brande, W.T. (1820) On a substance produced during the distillation of coal tar. $Q$ J Sci 8: 287-290. 
Caldwell, M.E., and Suflita, J.M. (2000) Detection of phenol and benzoate as intermediates of anaerobic benzene biodegradation under different terminal electron-accepting conditions. Environ Sci Technol 34: 1216-1220.

Callaghan, A.V., Wawrik, B., Ni Chadhain, S.M., Young, L.Y., and Zylstra, G.J. (2008) Anaerobic alkane-degrading strain AK-01 contains two alkylsuccinate synthase genes. Biochem Biophys Res Commun 366: 142-148.

Chen, J., Henderson, G., Grimm, C.C., Lloyd, S.W., and Laine, R.A. (1998a) Termites fumigate their nests with naphthalene. Nature 392: 558-559.

Chen, J., Henderson, G., Grimm, C.C., Lloyd, S.W., and Laine, R.A. (1998b) Naphthalene in Formosan subterranean termite carton nests. J Agric Food Chem 46: 23372339.

Clauser, K.R., Baker, P., and Burlingame, A.L. (1999) Role of accurate mass measurement $(t /-10 \mathrm{ppm})$ in protein identification strategies employing MS or MS/MS and database searching. Anal Chem 71: 2871-2882.

Coates, J., Anderson, R., and Lovley, D. (1996) Oxidation of polycyclic aromatic hydrocarbons under sulfate-reducing conditions. App/ Environ Microbio/ 62: 1099-1101.

Coates, J., Woodward, J., Allen, J., Philp, P., and Lovley, D.R. (1997) Anaerobic degradation of polycyclic aromatic hydrocarbons and alkanes in petroleum-contaminated marine harbor sediments. Appl Environ Microbiol 63: 3589-3593.

Cord-Ruwisch, R. (1985) A quick method for the determination of dissolved and precipitated sulfides in cultures of sulfate-reducing bacteria. J Microbiol Methods 4: 33-36.

Daisy, B.H., Strobel, G.A., Castillo, U., Ezra, D., Sears, J., Weaver, D.K., and Runyon, J.B. (2002) Naphthalene, an insect repellent, is produced by Muscodor vitigenus, a novel endophytic fungus. Microbiology 148: 3737-3741.

Davidova, I.A., Gieg, L.M., Duncan, K.E., and Suflita, J.M. (2007) Anaerobic phenanthrene mineralization by a carboxylating sulfate-reducing bacterial enrichment. ISME J1: 436-442.

Dean, J.A. (1992) Lange's Handbook of Chemistry. New York, USA: McGraw-Hill.

Eastcott, L., Shiu, W.Y., and Mackay, D. (1988) Environmentally relevant physical-chemical properties of hydrocarbons: a review of data and development of simple correlations. Oil Chem Poll 4: 191-216.

Ezra, D., Hess, W.M., and Strobel, G.A. (2004) New endophytic isolates of Muscodor albus, a volatile-antibioticproducing fungus. Microbiology 150: 4023-4031.

Franck, H.-G., and Stadelhofer, J.W. (1987) Industrielle Aromatenchemie. Berlin, Germany: Springer-Verlag.

Galushko, A., Minz, D., Schink, B., and Widdel, F. (1999) Anaerobic degradation of naphthalene by a pure culture of a novel type of marine sulphate-reducing bacterium. Environ Microbiol 1: 415-420.

Galushko, A.S., Kiesele-Lang, U., and Kappler, A. (2003) Degradation of 2-methyinaphthalene by a sulfate-reducing enrichment culture of mesophilic freshwater bacteria. Polycyclic Aromatic Compounds 23: 207-218.

Garden, A. (1820) Singular substance found in a coal tar apparatus. Ann Phil 15: 74-75.

Gassett, J.W., Wiesler, D.P., Baker, A.G., Osborn, D.A., Miller, K.V., Marchinton, R.L., and Novotny, M. (1997)
Volatile compounds from the forehead region of male white-tailed deer (Odocoileus virginianus). $J$ Chem Ecol 23: 569-578.

Gibson, D.T., and Subramanian, V. (1984) Microbial degradation of aromatic compounds. In Microbial Degradation of Organic Compounds. Gibson, D.T. (ed.). New York, NY, USA: Marcel Dekker, pp. 181-252.

Gordon, D. (2004) Viewing and editing assembled sequences using Consed. In Current Protocols in Bioninformatics. Baxevanis, A.D., and Davison, D.B. (eds). New York, NY, USA: John Wiley, pp. 11.2.1-11.2.43.

Grundmann, O., Behrends, A., Rabus, R., Amann, J., Halder, T., Heider, J., and Widdel, F. (2008) Genes encoding the candidate enzyme for anaerobic activation of $n$-alkanes in the denitrifying bacterium, strain HxN1. Environ Microbiol 10: 376-385.

Habe, H., and Omori, T. (2003) Genetics of polycyclic aromatic hydrocarbon metabolism in diverse aerobic bacteria. Biosci Biotechnol Biochem 67: 225-243.

Harms, G., Zengler, K., Aeckersberg, F., Minz, D., Rabus, R., and Widdel, F. (1999) Anaerobic oxidation of o-xylene, $m$-xylene, and homologous alkylbenzenes by new types of sulfate-reducing bacteria. Appl Environ Microbiol 65: 9991004.

Hayes, L.A., and Lovley, D.R. (2002) Specific 16S rDNA sequences associated with naphthalene degradation under sulfate-reducing conditions in harbor sediments. Microb Ecol 43: 134-145.

Hayes, L.A., Nevin, K.P., and Lovley, D.R. (1999) Role of prior exposure on anaerobic degradation of naphthalene and phenanthrene in marine harbor sediments. Org Geochem 30: 937-945.

Heider, J. (2007) Adding handles to unhandy substrates: anaerobic hydrocarbon activation mechanisms. Curr Opin Chem Biol 11: 188-194.

Hicks, R.E., Amann, R.l., and Stahl, D.A. (1992) Dual staining of natural bacterioplankton with 4',6-diamidino-2phenylindole and fluorescent oligonucleotide probes targeting kingdom-level 16S rRNA sequences. App/ Environ Microbiol 58: 2158-2163.

Hufnagel, P., and Rabus, R. (2007) Mass spectrometric identification of proteins in complex post-genomic projects. Soluble proteins of the metabolic versatile, denitrifying 'Aromatoleum' sp. strain EbN1. J Mol Microbiol Biotechnol 11: $53-81$.

Kane, M.D., Poulsen, L.K., and Stahl, D.A. (1993) Monitoring the enrichment and isolation of sulfate-reducing bacteria by using oligonucleotide hybridization probes designed from environmentally derived $165 \mathrm{rRNA}$ sequences. Appl Environ Microbiol 59: 682-686.

Karlsson, A., Parales, J.V., Parales, R.E., Gibson, D.T., Eklund, H., and Ramaswamy, S. (2003) Crystal structure of naphthalene dioxygenase: side-on binding of dioxygen to iron. Science 299: 1039-1042.

Kidd, J. (1821) Observations on naphthaline, a peculiar substance resembling a concrete essential oil, which is apparently produced during the decomposition of coal tar, by exposure to a red heat. Philos Trans $R$ Soc Lond 111: 209-221.

Kniemeyer, O., Fischer, T., Wilkes, H., Glöckner, F.O., and Widdel, F. (2003) Anaerobic degradation of ethylbenzene 
by a new type of marine sulfate-reducing bacterium. Appl Environ Microbiol 69: 760-768.

Krauss, M., Wilcke, W., Martius, C., Bandeira, A.G., Garcia, M.V.B., and Amelung, W. (2005) Atmospheric versus biological sources of polycyclic aromatic hydrocarbons (PAHs) in a tropical rain forest environment. Environ Pollut 135: 143-154.

Kumar, S., Tamura, K., and Nei, M. (2004) MEGA3: integrated software for molecular evolutionary genetics analysis and sequence alignment. Brief Bioinform 5: 150-163.

Langenhoff, A.A.M., Zehnder, A.J.B., and Schraa, G. (1996) Behaviour of toluene, benzene and naphthalene under anaerobic conditions in sediment columns. Biodegradation 7: $267-274$.

Ludwig, W., Strunk, O., Westram, R., Richter, L., Meier, H., Yadhukumar, et al. (2004) ARB: a software environment for sequence data. Nucleic Acids Res 32: 13631371.

McMillen, D.F., and Golden, D.M. (1982) Hydrocarbon bond dissociation energies. Ann Rev Phys Chem 33: 493-532.

Meckenstock, R.U., Annweiler, E., Michaelis, W., Richnow, H.H., and Schink, B. (2000) Anaerobic naphthalene degradation by a sulfate-reducing enrichment culture. Appl Environ Microbiol 66: 2743-2747.

Musat, F., and Widdel, F. (2008) Anaerobic degradation of benzene by a marine sulfate-reducing enrichment culture, and cell hybridization of the dominant phylotype. Environ Microbiol 10: 10-19.

Phelps, C.D., Kerkhof, L.J., and Young, L.Y. (1998) Molecular characterization of a sulfate-reducing consortium which mineralizes benzene. FEMS Microbiol Ecol 27: 269-279.

Preuss, R., Angerer, J.R., and Drexler, H. (2003) Naphthalene - an environmental and occupational toxicant. Int Arch Occup Environ Health 76: 556-576.

Rabus, R., and Heider, H. (1998) Initial reactions of anaerobic metabolism of alkylbenzenes in denitrifying and sulfatereducing bacteria. Arch Microbiol 170: 377-384.

Rabus, R., Wilkes, H., Behrends, A., Armstroff, A., Fischer, T., Pierik, A.J., and Widdel, F. (2001) Anaerobic initial reaction of $n$-alkanes in a denitrifying bacterium: evidence for (1-methylpentyl)succinate as initial product and for involvement of an organic radical in $n$-hexane metabolism. $J$ Bacteriol 183: 1707-1715.

Rabus, R., Kube, M., Beck, A., Widdel, F., and Reinhardt, R. (2002) Genes involved in the anaerobic degradation of ethylbenzene in a denitrifying bacterium, strain EbN1. Arch Microbiol 178: 506-516.

Reed, D.R., and Kass, S.R. (2000) Experimental determination of the $\alpha$ and $\beta \mathrm{C}-\mathrm{H}$ bond dissociation energies in naphthalene. J Mass Spectrom 35: 534-539.

Rockne, K.J., and Strand, S.E. (1998) Biodegradation of bicyclic and polycyclic aromatic hydrocarbons in anaerobic enrichments. Environ Sci Technol 32: 3962-3967.

Rockne, K.J., and Strand, S.E. (2001) Anaerobic biodegradation of naphthalene, phenanthrene, and biphenyl by a denitrifying enrichment culture. Water Res 35: 291-299.

Rockne, K.J., Chee-Sanford, J.C., Sanford, R.A., Hedlund, B.P., Staley, J.T., and Strand, S.E. (2000) Anaerobic naphthalene degradation by microbial pure cultures under nitrate-reducing conditions. Appl Environ Microbiol 66: 1595-1601.
Rothermich, M.M., Hayes, L.A., and Lovley, D.R. (2002) Anaerobic, sulfate-dependent degradation of polycyclic aromatic hydrocarbons in petroleum-contaminated harbor sediment. Environ Sci Technol 36: 4811-4817.

Safinowski, M., and Meckenstock, R.U. (2006) Methylation is the initial reaction in anaerobic naphthalene degradation by a sulfate-reducing enrichment culture. Environ Microbio/ 8: 347-352.

Safinowski, M., Griebler, C., and Meckenstock, R.U. (2006) Anaerobic cometabolic transformation of polycyclic and heterocyclic aromatic hydrocarbons: evidence from laboratory and field studies. Environ Sci Technol 40: 41654173.

Sharak Genthner, B.R., Townsend, G.T., Lantz, S.E., and Mueller, J.G. (1997) Persistence of polycyclic aromatic hydrocarbon components of creosote under anaerobic enrichment conditions. Arch Environ Contam Toxicol 32: 99-105.

Sullivan, E.R., Zhang, X., Phelps, C., and Young, L.Y. (2001) Anaerobic mineralization of stable isotope-labeled 2-methylnaphthalene. Appl Environ Microbiol 67: 43534357.

Thierrin, J., Davis, G.B., Barber, C., Patterson, B.M., Pribac, F., Power, T.R., and Lambert, M. (1993) Natural degradation rates of BTEX compounds and naphthalene in a sulfate-reducing groundwater environment. Hydrol Sci 38: 309-322.

Tissot, B.P., and Welte, D.H. (1984) Petroleum Formation and Occurrence, 2nd edn. New York, NY, USA: SpingerVerlag.

Umweltbundesamt (2007) Naphthalin/Naphthole und HumanBiomonitoring. Bundesgesundheitsbl Gesundheitsforsch Gesundheitsschutz 50: 1357-1364. doi:10.1007/s00103007-0342-3.

Walsby, A.E. (1994) Gas vesicles. Microbiol Rev 58: 94-144.

Widdel, F. (1988) Microbiology and ecology of sulfate- and sulfur-reducing bacteria. In Biology of Anaerobic Microorganisms. Zehnder, A.J.B. (ed.). New York, NY, USA: Wiley \& Sons, pp. 469-585.

Widdel, F., and Bak, F. (1992) Gram-negative mesophilic sulfate-reducing bacteria. In The Prokaryotes, 2nd edn. Balows, A., Trüper, H.G., Dworking, M., Harder, W., and Schleifer, K.-H. (eds). New York, NY, USA: Springer, pp. 3352-3378.

Widdel, F., Boetius, A., and Rabus, R. (2004) Anaerobic biodegradation of hydrocarbons including methane. In The Prokaryotes, 3rd edn, Vol. 2. Dworkin, M., Falkow, S., Rosenberg, E., Schleifer, K.-H., and Stackebrandt, E. (eds). New York, NY, USA: Springer-Verlag, pp. 10281049.

Widdel, F., Musat, F., Knittel, K., and Galushko, A. (2007) Anaerobic degradation of hydrocarbons with sulphate as electron acceptor. In Sulphate-Reducing Bacteria: Environmental and Engineered Systems. Barton, L.L., and Hamilton, W.A. (eds). Cambridge, UK: Cambridge University Press, pp. 265-303.

Wilkes, H., Boreham, C., Harms, G., Zengler, K., and Rabus, R. (2000) Anaerobic degradation and carbon isotopic fractionation of alkylbenzenes in crude oil by sulphate-reducing bacteria. Org Geochem 31: 101-115.

Wöhlbrand, L., Wilkes, H., Halder, T., and Rabus, R. (2008) 
Anaerobic degradation of $p$-ethylphenol by 'Aromatoleum aromaticum' strain EbN1: pathway, regulation, and involved proteins. J Bacteriol 190: 5699-5709.

Zhang, X., and Young, L.Y. (1997) Carboxylation as an initial reaction in the anaerobic metabolism of naphthalene and phenanthrene by sulfidogenic consortia. Appl Environ Microbiol 63: 4759-4764.

Zhou, J., Bruns, M.A., and Tiedje, J.M. (1996) DNA recovery from soils of diverse composition. Appl Environ Microbiol 62: 316-322.

\section{Supporting information}

Additional Supporting Information may be found in the online version of this article:

Fig. S1. Incubation experiments of strain NaphS2 with nontoxic concentrations of 1-naphthol indicating that it did not serve as a substrate.

Fig. S2. Mapping of peptides (identified by mass spectrometry) from 2-methylnaphthalene-specific proteins (Fig. 4) against the gene-deduced assumed (2-naphthylmethyl)succinate synthases in strains NaphS2, NaphS3 and NaphS6.

Fig. S3. CLUSTALW alignment of protein sequences used for phylogenetic tree construction (Fig. 5).

Fig. S4. Assumed separate degradation of naphthalene and 2-methylnaphthalene to the common intermediate, 2-naphthoyl-CoA, in marine sulfate-reducing bacteria.

Fig. S5. Isotope-based differentiation between the pathways of naphthalene and 2-methylnaphthalene in marine sulfatereducing bacteria.

Fig. S6. Partial ion chromatograms revealing naphthalene2-carboxylic acid methyl ester and methylnaphthalene-2carboxylic acid methyl esters obtained after growth with 2-methylnaphthalene or a mixture of naphthalene and 1-methylnaphthalene respectively.

Please note: Blackwell Publishing are not responsible for the content or functionality of any supporting materials supplied by the authors. Any queries (other than missing material) should be directed to the corresponding author for the article. 